\title{
EL IMPACTO PATOLÓGICO DEL DESCUBRIMIENTO DE AMÉRICA
}

\author{
FERNANDO CABIESES
}

UNIVERSIDAD CIENTIFICA DEL SUR

\begin{abstract}
El viaje de Colón fue el detonante para desarrollar el contacto directo entre dos grandes sectores de la humanidad que habian permanecido totalmente separados durante varios miles de años. Durante ese largo periodo de indiferencia mutua, cada grupo humano desarrollo independientemente sistemas de adaptación, reacción inmunitaria, evolución patológica y reacción final o muerte ante diversos elementos patológicos (gérmenes, virus, enfermedades infecciosas, etc.) cuya reacción humana evolucionó en forma totalmente separada. De tal manera, que los individuos de cualquiera de los dos grupos presentaban características disimiles en su forma de cuidarse de las enfermedades que los habian acompañado durante todo ese largo periodo de separación.
\end{abstract}

Una enfermedad consiste en la reacción que un organismo vivo presenta ante la invasión de una sustancia patógena. El organismo se defiende creando anticuerpos especiales y sistemas reactivos que pueden traducirse en un proceso inmunitario que, cuando falla o es insuficiente, termina con la muerte del individuo. Tanto a los europeos a fricanos y asiáticos como a los pueblos del Continente Americano, llegaron des de sus nuevos vecinos gérmenes que ya habian sido tolerados por un largo proceso de inmunización total o parcial en las áreas originales. Estos sistemas de defensa no existían en los grupos humanos que no habian sufrido, previamente, ninguna confrontación contra esos agentes patógenos. Hubo, por consiguiente, trágicas invasiones de nuevos actores dañinos en poblaciones, totalmente indefensas, que sufrieron el cruel impacto $\sin$ la menor protección. Los resultados fueron dramáticos, trágicos y destructivos de importantes civilizaciones en los grupos humanos recipientes y victimas.

En un resumen de este muy amplio tema sería imposible relatar, en detalle, la guerra de vida o muerte entre los invasores y los invadidos, lo que, naturalmente, produjo lo más terribles epidemias mortales que formaron parte del resultado ulterior del viaje de Colón.
El impacto sufrido por las poblaciones america" nas se produjo precisamente en el Caribe donde se desarrolló una mortal epidemia de gripe o de influenza que en los primeros años diezmó a toda la población indígena. Ahora sabemos que esto fue producido por el virus de la encefalitis porcina, traída por los españoles quienes obligaban a su propia tripulación y tropas y a todos los pueblos conquistados a comer carne de puerco para evitar que se infiltrasen ideologías anticristianas (Moisés y Mahoma) provenientes de la raíz de Abraham. que prohibió la carne de cerdo hasta estos dias.

Los españoles invasores estaban relativamente adaptados a ese virus y la epidemia solamente produjo la destrucción en altísimo porcentaje de la población indigena. Un siglo más tarde, casi todos los nativos habían desaparecido como pue de verse ahora si uno visita el Caribe y no encuentra población indigena la que fue reemplazada por una población africana que vino en el cruel tráfico esclavista. De inmediato, siguió una terrible epidemia que invadió el Caribe y México continuando la destrucción de la raza indígena con el virus de la viruela que produjo horrorosos y crueles estragos durante esta segunda batalla bacteriológica. Los africanos se unieron a los españoles para traer a América la mortal epidemia de Malaria que no había existido en la América Precolombina y que continúo diezmando a la población nativa.

En el Perú, la población del Imperio Inca sufrî́o una horrorosa destrucción al llegar los españoles enfermos de viruela durante el segundo viaje de Pizarro en 1,527. Cuando Pizarro llegó en su tercer viaje $(1,532)$ prácticamente toda la nobleza di. rigente del Tahuantinsuyo habia muerto con la vit. ruela. Entre ellos, el gran Inca Huayna Cápac y su principal heredero Ninan Cuyoche dejando en una anquilosante guerra fraticida y a sus dos hijos. Virus varioloso agregó cal y arena a la sepultura del mayor imperio del mundo conocido en esos tiempos.

Si bien muchos aceptan que España contribuyớ a civilizar a los pueblos nativos del Perú, un chispa- 
zo de humor negro nos recuerda que el Perú contribuyó a civilizar a España y a todo el mundo. La sífilis se expandió, en forma muy virulenta, entre los pueblos europeos y africanos que no tenían defensas que los protegieran para defenderse de tan cruel germen.

Siguió el intercambio. Vino también desde Chipre, a travês de los soldados españoles, la imparable epidemia del tifus que, con el nombre de "modorra", enfermó a muchos españoles pero mató a muchos indios aumentando en forma mágico-religiosa la presencia de nuevas enfermedades como castigo de Dios -decían los sacerdotes evangelizadores- por las caracteristicas sobrevivientes de las idolatrías y supersticiones indígenas.

La fiebre amarilla fue otro de los crueles impactos que la invasión de europeos y africanos produjo en la población indígena. Este trágico enemigo, al igual que la malaria, vino acompañada de su mosquito transmisor que hizo el viaje. Iban en las provisiones de agua que trafan los bajeles españoles en su largo viaje intercontinental.
Podriamos seguir enumerando estos terribles intercambios patológicos que fueron el corolario inhumano del viaje de Colón y de los que lo siguieron. Afortunadamente, muchas de estas enfermedades importadas fueron prontamente controladas por la medicina indígena, un cuerpo de doctrina que siguió funcionando después de la invasión cristiana para controlar las terribles epidemias y fue precisamente la medicina peruana antigua la que, en el término de un siglo de muerte y depredación, logró controlar esta terrible enfermedad de la malaria mediante un árbol que todavía veneramos en nuestro Escudo Nacional y que fue también, a través de medicamentos naturales indígenas, como la quinina, el paico, el oje, la ipecacuana, y alrededor de 60 medicamentos naturales que invadieron la medicina Renacentista europea con la fuerza cultural de la medicina peruana que después, poco a poco, lentamente, ha sido siendo reemplazado por la alquimia evolucionada hacia la ciencia farmacéutica moderna. 